\title{
Development of improved catalysts for deep HDS of diesel fuels
}

\author{
Syed Ahmed Ali
}

Received: 20 June 2014 / Accepted: 29 July 2014/Published online: 20 August 2014

(C) The Author(s) 2014. This article is published with open access at Springerlink.com

\begin{abstract}
Deep hydrodesulfurization (HDS) of gas oils continues to attract research interest due to environmentaldriven regulations which limit its sulfur content to $10-15 \mathrm{ppm}$ in several countries. This paper highlights some of the recent studies conducted at King Fahd University of Petroleum and Minerals to develop improved HDS catalysts. The first study was focused on the effect of $\mathrm{Co} /(\mathrm{Co}+\mathrm{Mo})$ ratio in $\mathrm{CoMo} / \mathrm{Al}_{2} \mathrm{O}_{3}$ catalysts on $\mathrm{HDS}$ pathways of benzothiophene (BT) and dibenzothiophene (DBT). $\mathrm{Co} / \mathrm{Co}+\mathrm{Mo}$ ratio exhibited significant influence on the direct desulfurization (DDS) pathway, but showed no influence on the hydrogenation pathway. A $\mathrm{Co} /$ $\mathrm{Co}+$ Mo ratio of 0.4 exhibited optimum promotion effect of Co for HDS by DDS route and hence overall HDS. The second study investigated the effect of phosphorus addition on simultaneous HDS reactions and their pathways. The results indicate that phosphorus modification of $\mathrm{CoMo} / \gamma$ $\mathrm{Al}_{2} \mathrm{O}_{3}$ catalysts resulted in enhancement of HDS due to increased dispersion of $\mathrm{MoO}_{3}$ and the maximum enhancement was achieved with $1.0 \quad$ wt $\% \quad \mathrm{P}_{2} \mathrm{O}_{5}$. Enhancement of HDS rates was in the following order: 4,6DMDBT $(51 \%)>4$-MDBT $(38 \%)>$ DBT $(26 \%)$. In the third approach, a series of NiMo catalysts supported on $\mathrm{Al}_{2} \mathrm{O}_{3}-\mathrm{ZrO}_{2}$ composites containing $0-10$ wt $\% \mathrm{ZrO}_{2}$ was synthesized, characterized and evaluated for deep desulfurization of gas oil. An increase of 1.3-2.5 times increase
\end{abstract}

Electronic supplementary material The online version of this article (doi:10.1007/s13203-014-0082-x) contains supplementary material, which is available to authorized users.

\section{S. A. Ali $(\square)$}

Center of Research Excellence in Petroleum Refining and

Petrochemicals, King Fahd University of Petroleum and

Minerals, Dhahran 31261, Saudi Arabia

e-mail: ahmedali@kfupm.edu.sa in HDS activity at $320-360{ }^{\circ} \mathrm{C}$ was observed due to reduced interaction between $\mathrm{Al}_{2} \mathrm{O}_{3}$ and the active metals. A correlation was found between the enhancement of hydrogenation activity of sulfided catalysts and the reducibility of their oxide precursors.

Keywords Arabian gas oils · Hydrodesulfurization · HDS pathways $\cdot \mathrm{CoMo} / \mathrm{Al}_{2} \mathrm{O}_{3} \cdot \mathrm{NiMo} / \mathrm{Al}_{2} \mathrm{O}_{3}-\mathrm{ZrO}_{2}$

\section{Introduction}

Global trend in diesel sulfur limit is towards $10-15 \mathrm{ppm}$ levels, which is required to adopt advanced pollution control technologies. With increase in heavy/sour crude production, the requirement for deep desulfurization will increase all over the world, especially in fast growing regions of Asia-Pacific and Middle East. Advanced processes/catalysts are required to meet the specifications and increasing demands of ultra-low sulfur diesel [5, 15]. Ultralow sulfur levels (10-15 ppm) can be achieved by deep hydrodesulfurization (HDS) of middle distillate streams. Many factors such as the catalysts, process parameters, and feedstock quality have a significant influence on the degree of desulfurization of diesel feeds.

Detailed analysis of gas oils obtained from Arabian Light (AL-GO), Arabian Medium (AM-GO) and Arabian Heavy (AH-GO) crude oils in terms of reactive and refractory sulfur, nitrogen, as well as aromatic species has been reported [7]. The sulfur, nitrogen and aromatic contents were considerably higher in AH-GO as presented in Table 1. Refractory sulfur and the alkyl-carbazole content in the AH-GO, which are significantly (3-4 times) higher than that in AL-GO, hinders the deep HDS of AH-GO. Major sulfur species were alkyl-benzothiophenes (alkyl- 
Table 1 Aromatics, sulfur and nitrogen species in arabian gas oils [7]

\begin{tabular}{llll}
\hline Component & \multicolumn{3}{l}{ Type of gas oil hydrotreated } \\
\cline { 2 - 4 } & AL-GO & AM-GO & AH-GO \\
\hline $\begin{array}{l}\text { Total aromatics (\%) } \\
\text { Sulfur (ppm) }\end{array}$ & 21 & 25 & 32 \\
$\quad$ Reactive & 4,134 & 4,741 & 6,500 \\
Refractive & 3,567 & 5,859 & 10,500 \\
Total & 7,701 & 10,600 & 17,000 \\
Nitrogen (ppm) & & & \\
Carbazole & 1.4 & 3.1 & 4.3 \\
Alkyl carbazole & 84.0 & 95.0 & 308.0 \\
Total & 85.4 & 98.1 & 312.3 \\
\hline
\end{tabular}

Reproduced with permission from Elsevier

BTs) comprising C2-C5 alkyl chain, dibenzothiophene (DBT), as well as the considerable amounts of alkyl-DBTs, such as 4-DBT, 4,6- DMDBT and 4,6,x-TMDBT. AH-GO contained the largest amount of alkyl-DBTs with two or more alkyl carbon atoms, which are the refractory sulfur species. The results also show presence of significantly higher nitrogen content in AH-GO, which are mainly alkylcarbazoles.

The conventional HDS process is usually conducted over sulfided $\mathrm{CoMo} / \gamma-\mathrm{Al}_{2} \mathrm{O}_{3}$ or $\mathrm{NiMo} / \gamma-\mathrm{Al}_{2} \mathrm{O}_{3}$ catalysts. A variety of metal contents, promoters, support properties, etc., have been studied and used for the development of versatile deep HDS catalyst system. Despite their robust nature, conventional catalysts, however, do not have sufficient activity to desulfurize diesel feed streams to ultralow sulfur levels under normal operating conditions. They require severe operating conditions such as high temperature, low space velocity and high hydrogen partial pressure. Such severe processing conditions generally lead to rapid catalyst deactivation, shorter cycle lengths and reduced throughput.

Hence, the development and application of highly active and stable catalysts are among the most desired options for reducing the sulfur content of diesel to ultra-low levels by deep desulfurization. Substantial improvement in catalyst activity is necessary when the sulfur content is to be reduced to ultra-low levels $(<15 \mathrm{ppm})$. This was achieved by one or more of the following approaches: (a) nature of active species; (b) support choice and modification; and (c) preparation procedures. Intensive efforts have been devoted to develop highly active hydrodesulfurization (HDS) catalysts [15].

The paper highlights the results from some of the recent studies conducted at the Center for Refining and Petrochemicals of the King Fahd University of Petroleum and Minerals (KFUPM) to develop improved HDS catalysts.
The studies covered include (a) effect of $\mathrm{Co} /(\mathrm{Co}+\mathrm{Mo})$ ratio in $\mathrm{CoMo} / \mathrm{Al}_{2} \mathrm{O}_{3}$ catalysts on HDS pathways of benzothiophene and dibenzothiophene; (b) role of phosphorus addition on simultaneous HDS of dibenzothiophene and alkyl dibenzothiophenes over $\mathrm{CoMo} / \mathrm{Al}_{2} \mathrm{O}_{3}$ catalysts; and (c) deep HDS of gas oil over NiMo catalysts supported on $\mathrm{Al}_{2} \mathrm{O}_{3}-\mathrm{Zr}_{2} \mathrm{O}_{3}$ composites.

\section{Effect of $\mathrm{Co} /(\mathrm{Co}+\mathrm{Mo})$ ratio in $\mathrm{Como} / \gamma-\mathrm{Al}_{2} \mathrm{O}_{3}$ catalysts on HDS pathways}

The HDS of dibenzothiophenes generally takes place by two routes: (a) a hydrogenation (HYD) pathway involving aromatic ring hydrogenation, followed by $\mathrm{C}-\mathrm{S}$ bond cleavage; and (b) a direct desulfurization (DDS) or hydrogenolysis pathway via direct $\mathrm{C}-\mathrm{S}$ bond cleavage without aromatic ring hydrogenation [13]. The direct desulfurization route is favorable as it consumes less $\mathrm{H}_{2}$, making this route more economical. Therefore, many researchers have focused their research to enhance the DDS selectivity [8, 14, 17].

The objective of this study was to investigate the influence of $\mathrm{Co} /(\mathrm{Co}+\mathrm{Mo})$ ratio on the HDS of benzothiophene (BT) and dibenzothiophene (DBT). The study covered overall HDS as well the DDS and HYD pathways for HDS [1].

\section{Catalyst preparation and evaluation}

A series of $\mathrm{CoMo} / \gamma-\mathrm{Al}_{2} \mathrm{O}_{3}$ catalysts was prepared with $\mathrm{Co} /$ $(\mathrm{Co}+\mathrm{Mo})$ ratio of $0.3,0.4$ and 0.5 while maintaining a total metal oxide content of 19 wt \%. For the sake of simplicity, the catalysts were denoted as $a \mathrm{CM}$, in which $a$ represents ten times the $\mathrm{Co} /(\mathrm{Co}+\mathrm{Mo})$ molar ratio. The catalysts were prepared by co-impregnation of $\left(\mathrm{NH}_{4}\right)_{6} \mathrm{Mo}_{7} \mathrm{O}_{24} \bullet 4 \mathrm{H}_{2} \mathrm{O}$ and $\mathrm{Co}\left(\mathrm{NO}_{3}\right)_{2} \bullet 6 \mathrm{H}_{2} \mathrm{O}$ on calcined $\gamma-$ $\mathrm{Al}_{2} \mathrm{O}_{3}$ at room temperature. The actual $\mathrm{MoO}_{3}$ loadings were $15.4,14.0$ and 12.4 wt $\%$ for 3,4 and 5, respectively. The surface areas of 3,4 and 5 catalysts were 166, 155, $146 \mathrm{~m}^{2} / \mathrm{g}$ whereas their pore volumes were $0.33,0.28$ and $0.24 \mathrm{ml} / \mathrm{g}$, respectively. The oxide catalysts were sulfided prior to their performance tests by light kerosene spiked with dimethyl disulfide (2.5 wt \% sulfur) in a tubular reactor under flowing hydrogen $(7.5 \mathrm{NL} / \mathrm{h})$ at $750 \mathrm{psig}$ and $593 \mathrm{~K}$ for $16 \mathrm{~h}$.

The catalysts were tested in a $100 \mathrm{ml}$ batch autoclave reactor which was loaded with $50 \mathrm{~g}$ decalin and $0.105 \mathrm{~g}$ of BT and $0.144 \mathrm{~g}$ of DBT. Hence, the model compounds contributed $500 \mathrm{ppm}$ each of sulfur content, which resulted in a total sulfur content of 1,000 ppm in the feed. Half a gram of fresh catalyst was used for each experiment, which amounted to a catalyst-to-feedstock ratio of $1 \mathrm{wt} \%$. 
Table 2 Pseudo-first order reaction rate constants and activation energies for the HDS of BT and DBT [1]

\begin{tabular}{|c|c|c|c|c|c|}
\hline \multirow[t]{2}{*}{ Catalyst } & \multirow{2}{*}{$\begin{array}{l}\mathrm{Co} / \mathrm{Co}+\mathrm{Mo} \\
\text { molar ratio }\end{array}$} & \multirow{2}{*}{$\begin{array}{l}\text { Temperature } \\
\left({ }^{\mathrm{o}} \mathrm{C}\right)\end{array}$} & \multicolumn{2}{|c|}{$1,000 \times k\left(\min ^{-1}\right)$} & \multirow{2}{*}{$\begin{array}{l}k_{\mathrm{BT}} / \\
k_{\mathrm{DBT}}\end{array}$} \\
\hline & & & $k_{\mathrm{BT}}$ & $k_{\mathrm{DBT}}$ & \\
\hline \multirow[t]{3}{*}{$3 \mathrm{CM}$} & \multirow[t]{3}{*}{0.310} & 300 & 101 & 1 & 101 \\
\hline & & 325 & 139 & 5 & 28 \\
\hline & & 350 & 150 & 24 & 6.3 \\
\hline \multirow[t]{3}{*}{$4 \mathrm{CM}$} & \multirow[t]{3}{*}{0.407} & 300 & 108 & 10 & 10.8 \\
\hline & & 325 & 142 & 17 & 8.4 \\
\hline & & 350 & 166 & 48 & 3.5 \\
\hline \multirow[t]{3}{*}{$5 \mathrm{CM}$} & \multirow[t]{3}{*}{0.505} & 300 & 90 & 5 & 18 \\
\hline & & 325 & 106 & 8 & 13.3 \\
\hline & & 350 & 152 & 24 & 6.3 \\
\hline
\end{tabular}

Reproduced with permission from Springer

Experiments were carried out for $2 \mathrm{~h}$ under a hydrogen pressure (6.1 MPa) and at 573, 598 and $623 \mathrm{~K}$. The product samples taken during the course of the experimental run were analyzed by gas chromatograph equipped with sulfur chemiluminscence detector (GC-SCD).

\section{Results and discussion}

HDS kinetics BT and DBT were determined by assuming a pseudo first-order reaction and the results are summarized in Table 2 [1]. Comparison of first-order rate constants obtained at different temperatures and catalysts provides information about the effectiveness of cobalt addition on BT and DBT desulfurization. The HDS rate of BT was much higher than DBT, especially at lower temperature. However, the HDS of DBT was more sensitive to $\mathrm{Co} /$ $(\mathrm{Co}+\mathrm{Mo})$ ratio than the HDS of BT. Overall HDS rates of BT and DBT were higher over 4CM catalyst than either $3 \mathrm{CM}$ or 5CM. Activation energies of the HDS of DBT were 3-4 times higher than the HDS of BT. Lowest activation energy for DBT was for 4CM.

HDS of DBT takes place via direct desulfurization (DDS) and/or Hydrogenation (HYD) routes. Cyclohexyl benzene content was almost same for products obtained over all catalysts indicating no influence of $\mathrm{Co} /(\mathrm{Co}+\mathrm{Mo})$ ratio on the HYD route. Biphenyl content was highest over 4CM which signifies that DDS is enhanced when the $\mathrm{Co} /$ $(\mathrm{Co}+\mathrm{Mo})$ ratio is 0.4 .

The results of this study have clearly demonstrated that $\mathrm{Co} / \mathrm{Co}+\mathrm{Mo}$ ratio has significant influence on the overall HDS of BT and DBT as well as on the DDS pathway, but showed no influence on the HYD pathway. A Co/Co $+\mathrm{Mo}$ ratio of 0.4 was found to be optimum for both overall HDS as well as the HDS by DDS pathway.

\section{Role of $P$ addition on simultaneous HDS of DBT and alkyl DBTs over $\mathrm{CoMo} / \mathrm{Al}_{2} \mathrm{O}_{3}$ catalysts}

Previous studies have shown that modification of HDS catalysts by acidic species, such as phosphorus, improves the activities of $\mathrm{Mo} / \gamma-\mathrm{Al}_{2} \mathrm{O}_{3}$ catalysts [9, 10]. However, most of the earlier studies focused on influence of phosphorus on HDS catalysts using single model compound. In the present study, simultaneous HDS of DBT and 4-methyl dibenzothiophene (4-MDBT) as well as DBT and 4,6DMDBT were studied over a series of phosphorus promoted $\mathrm{CoMo} / \gamma-\mathrm{Al}_{2} \mathrm{O}_{3}$ catalysts with the aim of investigating the effect of phosphorus addition on simultaneous HDS reactions. The study covered overall HDS as well as the DDS and HYD pathways for HDS [3].

Catalyst preparation and evaluation

A series of catalysts was prepared in which the total metal oxide $\left(\mathrm{MoO}_{3}+\mathrm{CoO}\right)$ content was kept constant at 19.0 wt $\%$ with a $\mathrm{Co} /(\mathrm{Co}+\mathrm{Mo})$ ratio of 0.4 . $\gamma$-alumina support was modified by addition of $0.5,1.0$ or 1.5 wt $\%$ of $\mathrm{P}_{2} \mathrm{O}_{5}$ before impregnation of the active metals. The catalysts were prepared by co-impregnation of ammonium heptamolybedate tetrahydrate and cobalt nitrate heaxahydrate on calcined $\gamma$-alumina at room temperature. The catalysts were then dried at $373 \mathrm{~K}$ for $12 \mathrm{~h}$ followed by calcination at $773 \mathrm{~K}$ for $1 \mathrm{~h}$. The catalysts were denoted as $\operatorname{CMP}(a)$, in which $a$ represents $\mathrm{P}_{2} \mathrm{O}_{5}$ content in wt $\%$.

Figure 1 shows the pore size distribution of phosphorus modified and unmodified catalysts. Phosphate is adsorbed on the walls of the pores and blocks small pores initially resulting in stronger reduction in pore volume (up to $35 \%$ ) than surface area (up to $26 \%$ ). The apparent average size of unblocked pores increases due to phosphate adsorption. However, in reality, there was slight decrease in pore size that was originally present in $\mathrm{CMP}(0)$ catalyst due to adsorption of $\mathrm{P}_{2} \mathrm{O}_{5}$. This phenomenon results in decrease in surface area, pore volume and average pore size with increase in $\mathrm{P}_{2} \mathrm{O}_{5}$ content.

Catalyst evaluation procedures used were similar to those presented in Sect. 2.1. Two sets of experiments: (a) DBT and 4-MDBT; and (b) DBT and 4,6-DMDBT were carried out. The quantities of model compounds added in the decalin feedstock were controlled so that each model compound contributed $500 \mathrm{ppm}$ of sulfur in the feedstock.

\section{Results and discussion}

X-ray diffraction patterns of $\gamma-\mathrm{Al}_{2} \mathrm{O}_{3}$ and $\mathrm{CMP}$ catalysts show that the crystallinity of $\mathrm{CoMoO}_{4}$ phase increased with 


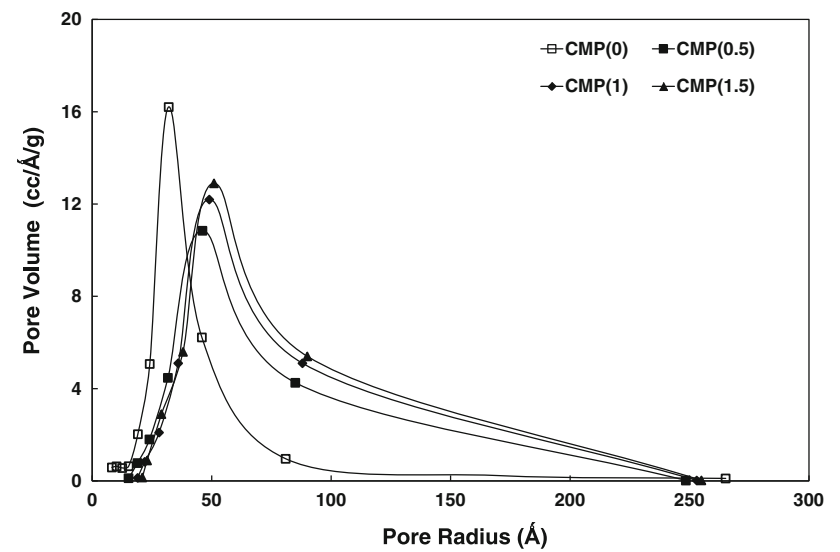

Fig. 1 Pore-size distribution of CMP catalysts [3]. (Reproduced with permission from Elsevier)

$\mathrm{P}$ addition. It also resulted in increased dispersion of $\mathrm{MoO}_{3}$ phase, which is catalytically active phase. Modification of $\mathrm{CoMo} / \gamma-\mathrm{Al}_{2} \mathrm{O}_{3}$ catalysts by addition of phosphorus strongly increased the HDS activity and the maximum activity enhancement was achieved with 1.0 wt $\% \mathrm{P}_{2} \mathrm{O}_{5}$. However, further increase in phosphorus content reduces the activity which may be due to enhanced $\mathrm{CoMoO}_{4}$ formation, as noticed from XRD results, causing loss of Mo dispersion and formation of relatively stable Co-Mo-P compounds.

Comparison of reaction rates for DDS and HYD pathways provide an insight into the reactivities of model compounds and effect of phosphorus addition on catalyst. In the simultaneous HDS of DBT and 4-MDBT both molecules mainly react by the DDS pathway and thus compete for the same DDS sites (Fig. 2). However, in the case of simultaneous HDS of DBT and 4,6-DMDBT, the latter preferably reacts over the HYD sites, while DBT reacts mainly over DDS sites (Fig. 3). Thus, DBT faces less competition from 4,6-DMDBT than from 4-MDBT for the DDS sites resulting in higher conversion of DBT in the presence of 4,6-DMDBT than 4-MDBT.

Figure 4 summarizes the enhancement in catalyst activity due to addition of $1 \mathrm{wt} \% \mathrm{P}_{2} \mathrm{O}_{5}$ by DDS and $\mathrm{HYD}$ pathways as well as the overall HDS at $623 \mathrm{~K}$. The results show that about $90 \%$ enhancement in HDS of DBT and 4-MDBT was via DDS route. This is in contrast to about $47 \%$ enhancement in 4,6-DMDBT enhancement was via DDS route. On the absolute basis, however, the overall enhancement in HDS rates by phosphorus addition was in the following order: 4,6-DMDBT $(51 \%)>4$-MDBT $(38 \%)>$ DBT $(26 \%)$. Incidentally, steric hindrance by methyl substituents also increases in the same order. Since 4,6-DMDBT is one of the most refractive sulfur compound in the diesel fuel, enhancement in its HDS rate by about $50 \%$ by phosphorus addition will substantially contribute in achieving the 10-15 ppm sulfur level.

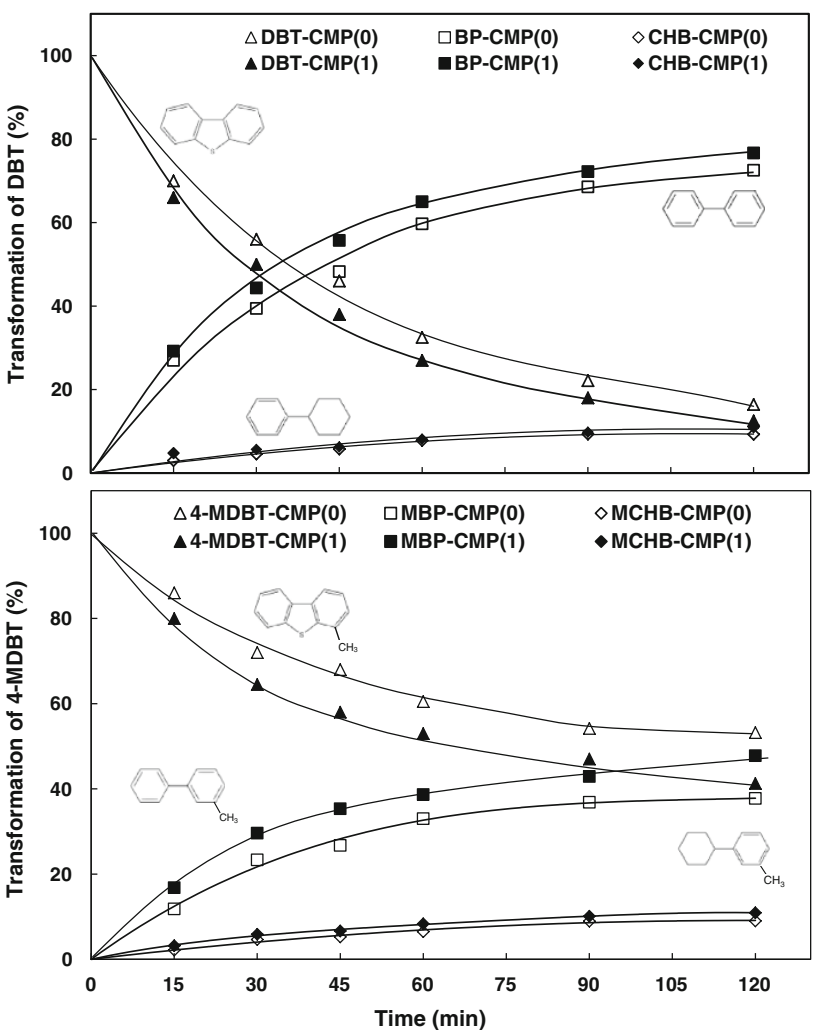

Fig. 2 Product distribution during simultaneous HDS of DBT and 4-MDBT over CMP(0) and CMP(1) catalysts at $623 \mathrm{~K}$ [3]. (Reproduced with permission from Elsevier)

\section{Deep HDS of gas oil over nimo catalysts supported on Alumina-Zirconia composites}

Alumina is the most widely used support material in HDS catalysts because it is highly stable, contains acidic and basic sites, has reasonably high surface area and porosity, can be easily formed into desired shapes, and is relatively inexpensive. However, alumina undergoes a direct interaction with the active metal species, and has an indirect role in determining the promotional effects of the secondary metal species. These effects have generated an immense interest in new supports for deep HDS catalysts, such as $\mathrm{TiO}_{2}, \mathrm{ZrO}_{2}, \mathrm{MgO}, \mathrm{C}, \mathrm{SiO}_{2}$, zeolites, etc. [6], [11], [12] [16]). Our study focused on the synthesis and characterization of a series of $\mathrm{ZrO}_{2}-\mathrm{Al}_{2} \mathrm{O}_{3}$ composite oxides containing 0-10 wt \% $\mathrm{ZrO}_{2}$ [2].

Catalyst preparation, characterization and evaluation

A series of $\mathrm{ZrO}_{2}-\mathrm{Al}_{2} \mathrm{O}_{3}$ composite supports having a $\mathrm{ZrO}_{2}$ content of $0.0,2.5,5.0$ and 10.0 wt $\%$ were prepared. Zirconium(IV) oxynitrate hydrate $\left[\mathrm{ZrO}\left(\mathrm{NO}_{3}\right)_{2} \bullet x \mathrm{H}_{2} \mathrm{O}\right]$ (99\%), ammonium heptamolybdate pentahydrate $\left[\left(\mathrm{NH}_{4}\right)_{6}\right.$ $\left.\mathrm{Mo}_{7} \mathrm{O}_{24} \bullet 5 \mathrm{H}_{2} \mathrm{O}\right](99.98 \%)$, and nickel(II) nitrate nonahydrate $\left[\mathrm{Ni}\left(\mathrm{NO}_{3}\right)_{2} \bullet 9 \mathrm{H}_{2} \mathrm{O}\right](98.5 \%)$ were used as sources of 


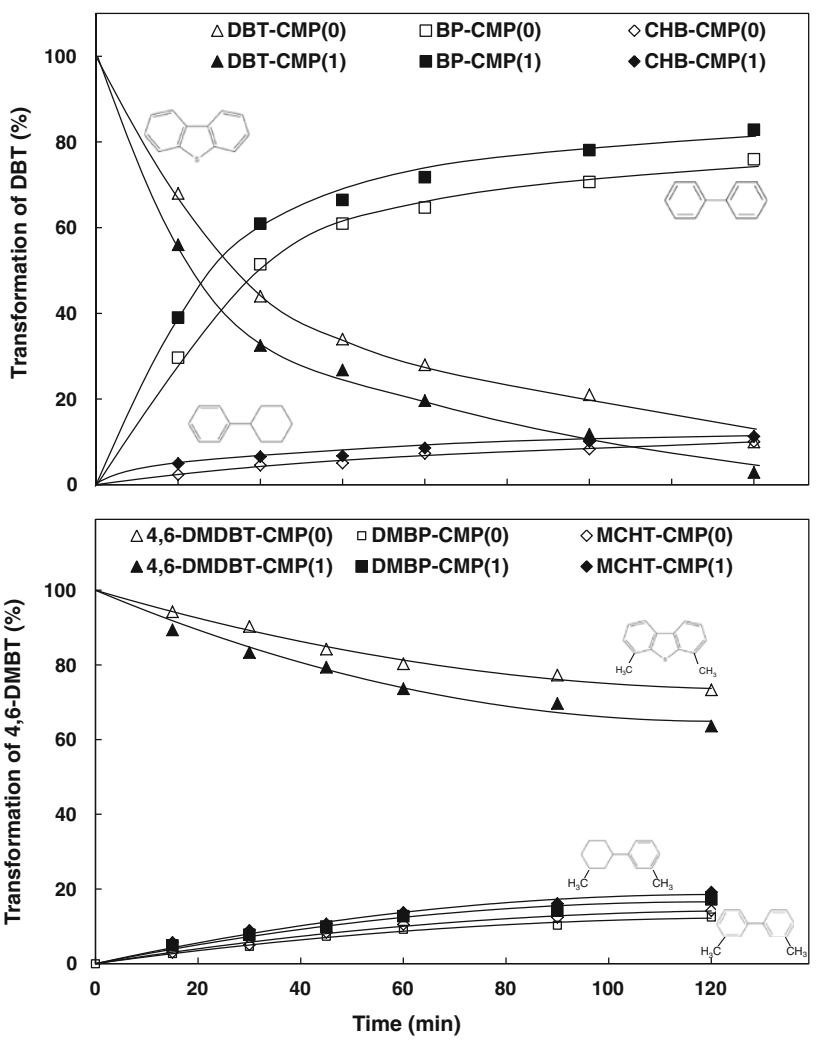

Fig. 3 Product distribution during simultaneous HDS of DBT and 4,6-DMDBT over $\mathrm{CMP}(0)$ and $\mathrm{CMP}(1)$ catalysts at $623 \mathrm{~K}$ [3] (Reproduced with permission from Elsevier)

zirconium, molybdenum and nickel, respectively. The composite supports were synthesized by peptizing $\mathrm{Al}_{2} \mathrm{O}_{3}$ together with $\mathrm{ZrO}\left(\mathrm{NO}_{3}\right)_{2} \bullet x \mathrm{H}_{2} \mathrm{O}$. Typical synthesis procedure involved dispersion of $40.0 \mathrm{~g} \mathrm{AlO}(\mathrm{OH}) \bullet \mathrm{H}_{2} \mathrm{O}$ in $200 \mathrm{ml}$ deionized water at $70{ }^{\circ} \mathrm{C}$ while stirring for $3 \mathrm{~h}$ followed by addition of $105 \mathrm{ml}$ aqueous solution of $\mathrm{ZrO}\left(\mathrm{NO}_{3}\right)_{2} \bullet x \mathrm{H}_{2} \mathrm{O}$. The concentration of $\mathrm{ZrO}\left(\mathrm{NO}_{3}\right)_{2} \bullet x \mathrm{H}_{2} \mathrm{O}$ was controlled in order to achieve $\mathrm{ZrO}_{2}$ contents of 0.0 , 2.5, 5.0 and $10.0 \mathrm{wt} \%$. An aqueous solution containing $\mathrm{Mo}, \mathrm{Ni}$ and citric acid in molar ratio of 1:0.4:1, respectively, was used to impregnate the supports with a loading of 18 wt $\% \mathrm{MoO}_{3}$ by pore-volume impregnation. The catalysts are referred to as NMAZ-0, NMAZ-2.5, NMAZ5 , and NMAZ-10, where the numbers denote the percentage of $\mathrm{ZrO}_{2}$ content.

$\mathrm{X}$-ray diffraction analysis of the supports was carried out on a Siemens-D5005 ${ }^{\circledR}$ diffractometer using $\mathrm{Cu}-\mathrm{K}_{\alpha}$ radiation under $40 \mathrm{kV}, 40 \mathrm{~mA}$, and scan range from $10^{\circ}$ to $80^{\circ}$. UV-Visible diffuse reflectance experiments were performed on a Thermo Evolution- $6000^{\circledR}$ high-performance spectrophotometer. A Quantachrome Autosorb-1C ${ }^{\circledR}$ system was used for temperature-programmed desorption of ammonia (NH3-TPD) of supports. $\mathrm{H}_{2}$ temperature-programmed reduction $\left(\mathrm{H}_{2}\right.$-TPR) was conducted on the catalysts after calcination in air at $550{ }^{\circ} \mathrm{C}$ for $3 \mathrm{~h}$. The

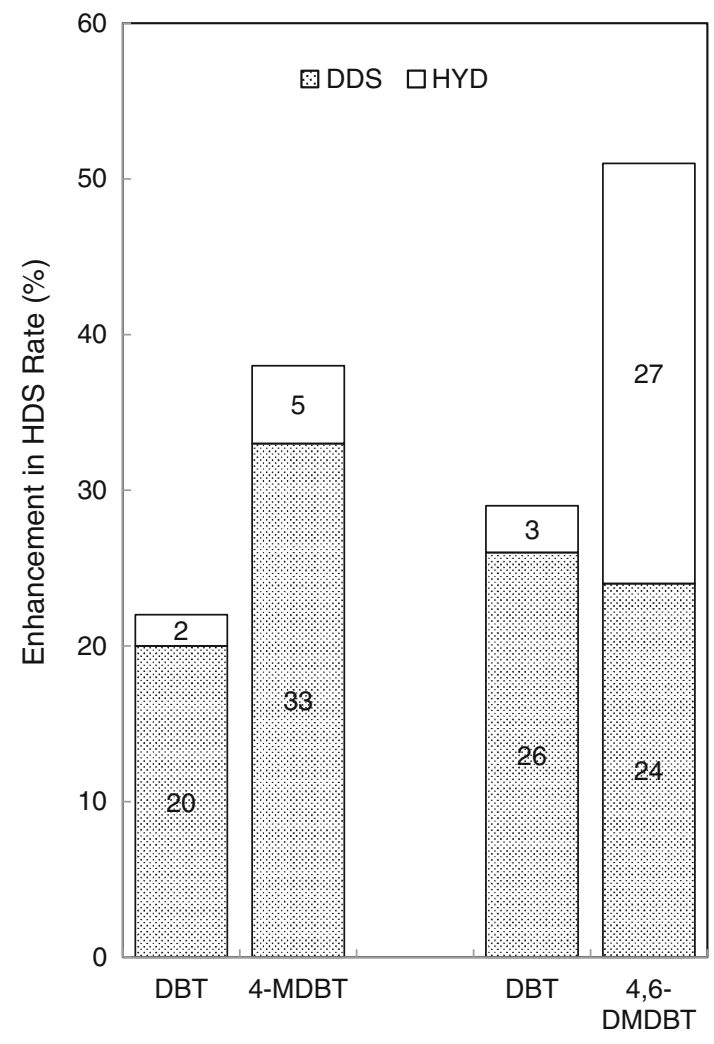

Fig. 4 Enhancement in HDS rates at $623 \mathrm{~K}$ due to addition of $1 \mathrm{wt} \%$ $\mathrm{P}_{2} \mathrm{O}_{5}$ [3] (Reproduced with permission from Elsevier)

composition of metals in the $\mathrm{ZrO}_{2}-\mathrm{Al}_{2} \mathrm{O}_{3}$ supports was quantitatively verified by inductively coupled plasma mass spectrometry (ICP-MS).

Catalytic activity for the HDS of gas oil was determined in a fixed-bed flow reaction system using gas oil feed ( $\mathrm{S}$ content $=10,000 \mathrm{ppm}$ ) which was obtained from a local refinery. The tubular reactor (ID $=1.5 \mathrm{~cm} ; \mathrm{L}=74 \mathrm{~cm}$ ) was loaded with $10 \mathrm{ml}$ of uncalcined catalyst as pellets of size between 0.50 and $0.85 \mathrm{~mm}$. Prior to performance testing, the catalyst was presulfided in situ using white kerosene mixed with dimethyl disulfide $(\mathrm{S}$ content $=2.5 \mathrm{wt} \%$ ). The performance of catalysts was evaluated at 320,340 and $360{ }^{\circ} \mathrm{C}$ while the LHSV $\left(1.0 \mathrm{~h}^{-1}\right), \mathrm{H}_{2}$ pressure $(6 \mathrm{MPa})$ and $\mathrm{H}_{2}$ flow rate $\left(250 \mathrm{Nm}^{3} / \mathrm{m}^{3}\right)$ were kept constant. Total sulfur content in the feed and product was determined by pyrofluorescence detection method using Antek 7000S analyzer. The boiling-range distribution was determined by simulated distillation using Agilent GC 3800.

\section{Results and discussion}

$\mathrm{X}$-ray diffraction patterns indicate homogenous dispersion of 2.5-10 wt $\%$ of $\mathrm{ZrO}_{2}$ in bulk $\mathrm{Al}_{2} \mathrm{O}_{3}$. Mono-modal poresize distribution-decrease in pore-size with increasing 
$\mathrm{ZrO}_{2}$ content. $\mathrm{NH}_{3}$-TPD results show that incorporation of 5 wt $\%$ or more $\mathrm{ZrO}_{2}$ neutralized the weak acid sites of $\mathrm{Al}_{2} \mathrm{O}_{3}$ and generated a different type of stronger acid sites. UV-Visible diffuse reflectance spectroscopy shows the presence of tetrahedral and octahedral $\mathrm{Mo}^{6+}$ ions species. An increase in octahedral species with addition of $\mathrm{ZrO}_{2}$ was observed, possibly due to weaker interaction of active metals on composite support. This result is also supported by $\mathrm{H}_{2}$-TPR measurements.

Acidity of the composite catalysts was assessed by $\mathrm{NH}_{3}$ TPD and the results are presented in Table 3 . It seems that the presence of $2.5 \% \mathrm{ZrO}_{2}$ has neutralized the strong acid sites on the $\mathrm{Al}_{2} \mathrm{O}_{3}$ supported catalyst and at the same time generated greater density of the weak ones. However, the density and strength of the strong acid sites increased in the $10 \% \mathrm{ZrO}_{2}$ supported catalyst. It could be postulated that the presence of $\mathrm{ZrO}_{2}$ has initially neutralized the strong acid sites, but upon further addition of $\mathrm{ZrO}_{2}$, stronger acid sites have evolved for the catalyst containing $10 \% \mathrm{ZrO}_{2}$. The exact nature of these acid sites, however, could not be identified in this study.

Deep desulfurization of gas oil, carried out in a benchscale flow reactor at 320,340 and $360{ }^{\circ} \mathrm{C}$, indicate that the addition of $\mathrm{ZrO}_{2}$ increased the catalytic activity-especially at higher temperature. The results are summarized in Table 4. Compared to $\mathrm{Al}_{2} \mathrm{O}_{3}$-based catalyst, the 1.5 order HDS rate constant was about 1.3, 1.8 and 2.5 times higher for catalysts containing $2.5,5$ and $10 \mathrm{wt} \% \mathrm{ZrO}_{2}$, respectively. Apparent activation energies were found to be in the range of $32-36 \mathrm{kcal} / \mathrm{mole}$, which are comparable to the reported values [4].

These trends confirm the results of $\mathrm{H}_{2}$-TPD characterization that the addition of $\mathrm{ZrO}_{2}$ reduces the interaction between $\mathrm{Al}_{2} \mathrm{O}_{3}$ support and the active metals, and led to the formation of the easily reduced Mo species, which formed more active sites. A correlation was also found between the enhancement of hydrogenation activity of sulfided catalysts and the reducibility of their oxide precursors, as determined by the amount of hydrogen consumed in TPR experiments followed by mass spectroscopy. The hydrogen consumption increased with increase in $\mathrm{ZrO}_{2}$ content indicating enhanced hydrogenation activity. This is perhaps the only major drawback of the incorporation of $\mathrm{ZrO}_{2}$ in the composite support.

Table $3 \mathrm{NH}_{3}$-TPD results of the of $\mathrm{NiMo} / \mathrm{Al}_{2} \mathrm{O}_{3}-\mathrm{ZrO}_{2}$ Catalysts [2]

\begin{tabular}{|c|c|c|c|c|c|}
\hline \multirow[t]{2}{*}{ Support } & \multicolumn{2}{|l|}{$80-350{ }^{\circ} \mathrm{C}$} & \multicolumn{2}{|l|}{$350-550{ }^{\circ} \mathrm{C}$} & \multirow[t]{2}{*}{ Total desorbed $\mathrm{NH}_{3}(\mu \mathrm{mol} / \mathrm{g})$} \\
\hline & $\begin{array}{l}\text { Peak } \\
\text { Temperature }\left({ }^{\circ} \mathrm{C}\right)\end{array}$ & $\begin{array}{l}\text { Desorbed } \mathrm{NH}_{3} \\
(\mu \mathrm{mol} / \mathrm{g})^{\mathrm{a}}\end{array}$ & $\begin{array}{l}\text { Peak } \\
\text { Temperature }\left({ }^{\circ} \mathrm{C}\right)\end{array}$ & $\begin{array}{l}\text { Desorbed } \\
\mathrm{NH}_{3}(\mu \mathrm{mol} / \mathrm{g})^{\mathrm{a}}\end{array}$ & \\
\hline AZ-0 & 165 & 15,250 & 435 & 3,327 & 18,577 \\
\hline AZ-2.5 & 166 & 64,139 & - & - & 64,139 \\
\hline AZ-5 & 170 & 23,675 & 380 & 1,112 & 24,787 \\
\hline AZ-10 & 187 & 8,752 & 482 & 1,531 & 10,283 \\
\hline
\end{tabular}

Reproduced with permission from Elsevier

a Obtained from the calibrated integrated intensity of the signal

Table 4 Performance evaluation results of $\mathrm{NiMo} / \mathrm{Al}_{2} \mathrm{O}_{3}-\mathrm{ZrO}_{2}$ catalysts [2]

\begin{tabular}{|c|c|c|c|c|c|c|c|c|c|c|c|c|c|}
\hline \multirow[b]{3}{*}{ Reaction temperature $\left({ }^{\circ} \mathrm{C}\right)$} & \multirow[t]{3}{*}{ Feed } & \multicolumn{12}{|c|}{ Catalyst } \\
\hline & & \multicolumn{3}{|c|}{ NMAZ-0 } & \multicolumn{3}{|c|}{ NMAZ-2.5 } & \multicolumn{3}{|c|}{ NMAZ-5 } & \multicolumn{3}{|c|}{ NMAZ-10 } \\
\hline & & 320 & 340 & 360 & 320 & 340 & 360 & 320 & 340 & 360 & 320 & 340 & 360 \\
\hline Sulfur content (wt ppm) & 10,000 & 1,390 & 579 & 114 & 1,180 & 399 & 66 & 767 & 213 & 30 & 389 & 117 & 20 \\
\hline \multicolumn{5}{|c|}{ Reduction in S content compared to NMAZ-0 (\%) } & 15 & 31 & 42 & 45 & 63 & 75 & 72 & 80 & 82 \\
\hline $\mathrm{H}_{2}$ consumption (NL/L) & & 19.8 & 28.9 & 36.7 & 23.2 & 33.9 & 46.7 & 26.5 & 42.6 & 53.2 & 29.5 & 47.8 & 62.8 \\
\hline Rate constant (1.5 order) & & 3.4 & 6.3 & 17.6 & 3.8 & 9.6 & 22.6 & 5.2 & 11.7 & 34.5 & 8.1 & 16.5 & 42.7 \\
\hline Apparent $\boldsymbol{E}_{\mathrm{a}}(\mathrm{kcal} / \mathrm{mol})$ & & & 32.1 & & & 33.2 & & & 35.4 & & & 35.5 & \\
\hline \multicolumn{14}{|l|}{ Simulated distillation $\left({ }^{\circ} \mathrm{C}\right)$} \\
\hline $5 \%$ & 179.9 & 181.6 & 180.6 & 178.4 & 183.2 & 179.7 & 176.2 & 183.8 & 178.2 & 173.1 & 184.4 & 179.7 & 170.0 \\
\hline $50 \%$ & 277.1 & 275.6 & 274.0 & 272.3 & 274.0 & 272.4 & 271.0 & 273.8 & 272.8 & 267.7 & 273.6 & 272.4 & 264.4 \\
\hline $95 \%$ & 357.0 & 348.2 & 343.1 & 350.5 & 339.4 & 338.0 & 357.8 & 351.0 & 354.6 & 336.5 & 362.6 & 338.0 & 315.2 \\
\hline
\end{tabular}

Reproduced with permission from Elsevier 


\section{Concluding remarks}

It has been demonstrated that development of deep HDS catalysts with improved performance can be achieved by different approaches:

(1) Incorporation of proper ratio of active metals effects DDS route of HDS. Highest DDS activity was observed at $\mathrm{Co} /(\mathrm{Co}+\mathrm{Mo})$ ratio of 0.4 . Since the total metal oxide content is fixed at $19 \mathrm{wt} \%$, higher Co content reduces Mo content and the catalytic activity. Lower Co content, on the other hand, results in not enough promotion of Mo catalytic activity.

(2) Addition of $\mathrm{P}_{2} \mathrm{O}_{5}$ as a second promoter weakens the interaction between $\mathrm{Mo}$ and $\gamma-\mathrm{Al}_{2} \mathrm{O}_{3}$ resulting in increased dispersion of $\mathrm{MoS}_{2}$ particles. Maximum activity enhancement was achieved with $1.0 \mathrm{wt} \%$ $\mathrm{P}_{2} \mathrm{O}_{5}$. However, further increase in phosphorus content reduces the activity which may be due to enhanced $\mathrm{CoMoO}_{4}$ formation causing loss of Mo dispersion.

(3) Application of $\mathrm{ZrO}_{3}-\mathrm{Al}_{2} \mathrm{O}_{3}$ composite support reduces the interaction between $\mathrm{Al}_{2} \mathrm{O}_{3}$ support and the active metals, and led to the formation of the easily reduced Mo species, which formed more active sites. A correlation was found between the enhancement of hydrogenation activity of sulfided catalysts and the reducibility of their oxide precursors.

These studies have contributed in increasing the understanding of scientific reasons for achieving improved performance of deep HDS catalysts. Among the different approaches studied, it is difficult to identify a single mosteffective method of catalyst improvement. It seems that several approaches need to be applied simultaneously to achieve the highest performing deep HDS catalysts.

Acknowledgments The author acknowledges the support of King Fahd University of Petroleum and Minerals (KFUPM). Acknowledgement is due to the Ministry of Higher Education, Saudi Arabia for establishing the Center of Research Excellence in Petroleum Refining and Petrochemicals (CoRE-PRP) at KFUPM. The author thanks Mr. Khurshid Alam for meticulously conducting the product analysis.

Open Access This article is distributed under the terms of the Creative Commons Attribution License which permits any use, distribution, and reproduction in any medium, provided the original author(s) and the source are credited.

\section{References}

1. Ahmed K, Ali SA, Ahmed S, Al-Saleh MA (2011) Simultaneous hydrodesulfurization of benzothiophene and dibenzothiophene over $\mathrm{CoMo} / \mathrm{Al}_{2} \mathrm{O}_{3}$ catalysts with different $[\mathrm{Co} /(\mathrm{Co}+\mathrm{Mo})]$ ratios. React Kinet Mech Catal 103:123-133

2. Al-Daous MA, Ali SA (2012) Deep desulfurization of gas oil over NiMo catalysts supported on alumina-zirconia composites. Fuel 97:662-669

3. Ali SA, Ahmed S, Ahmed KW, Al-Saleh MA (2012) Simultaneous hydrodesulfuriz-ation of dibenzotiophene and substituted dibenzothiophenes over phosphorus modified $\mathrm{CoMo} / \mathrm{Al}_{2} \mathrm{O}_{3}$ catalysts. Fuel Process Technol 98:39-44

4. Ancheyta J, Angeles MJ, Macias M, Marroquin G, Morales R (2002) Changes in apparent reaction order and activation energy in the hydrodesulfurization of real feedstocks. Energy Fuel 16:189-193

5. Barrow K (2009) More product-sulfur reduction on horizon. Oil Gas J 107:38-46

6. Breysse M, Afanasiev P, Geantet C, Vrinat M (2003) Overview of support effects in hydrotreating catalysts. Catal Today 86:5-16

7. Kim T, Ali SA, Alhooshani K, Park J-I, Al-Yami M, Yoon S-H, Mochida I (2013) Analysis and deep hydrodesulfurization reactivity of Saudi Arabian gas oils. J Ind Eng Chem 19:1577-1582

8. Kwak C, Kim MY, Choi K, Moon SH (1999) Effect of phosphorus addition on the behavior of $\mathrm{CoMoS} / \mathrm{Al}_{2} \mathrm{O}_{3}$ catalyst in hydrodesulfurization of dibenzothiophene and 4,6-dimethyldibenzothiophene. Appl Catal A Gen 185:19-27

9. Oyama ST, Gott T, Zhao H, Lee Y (2009) Transition metal phosphide hydroprocessing catalysts: a review. Catal Today 143:94-107

10. Prins R, Pirngruber G, Weber T (2001) Metal phosphides and zeolite-like mesophorus materials as catalysts. CHIMIA Int $\mathrm{J}$ Chem 55:791-795

11. Ramirez J, Sánchez-Minero F (2008) Support effects in the hydrotreatment of model molecules. Catal Today 130:267-271

12. Rayo P, Ramirez J, Rana MS, Ancheyta J, Aguilar-Elguézabal A (2009) Effect of the incorporation of $\mathrm{Al}, \mathrm{Ti}$, and $\mathrm{Zr}$ on the cracking and hydrodesulfurization activity of NiMo/SBA-15 catalysts. Ind Eng Chem Res 48:1242-1248

13. Shafi R, Hutchings GJ (2000) Hydrodesulfurization of hindered dibenzothiophenes: an overview. Catal Today 59:423-442

14. Shimada H, Sato T, Yoshimura Y, Hiraishi J, Nishijima A (1988) Support effect on the catalytic activity and properties of sulfided molybdenum catalysts. J Catal 110:275-284

15. Stanislaus A, Marafi A, Rana MS (2010) Recent advances in the science and technology of ultra-low sulfur diesel (ULSD). Catal Today 153:1-68

16. Trejo F, Rana MS, Ancheyta J (2008) CoMo/MgO- $\mathrm{Al}_{2} \mathrm{O}_{3}$ supported catalysts: an alternative approach to prepare HDS catalysts. Catal Today 130:327-336

17. Yao W, Zhongchao S, Anjie W (2004) Kinetics of hydrodesulfurization of dibenzothiophene catalyzed by sulfided $\mathrm{Co}-\mathrm{Mo} /$ MCM-41. Ind Eng Chem Res 43:2324-2329 